\title{
A Study of Related Factors Impacting on English Foreign Language Students' English Comprehension and Production in Classrooms
}

\author{
Patumporn Boonchum \\ English Program, the Faculty of Humanities and Social Sciences, \\ Pibulsongkram Rajabhat University \\ Thailand, 65000
}

\begin{abstract}
This study investigated factors which had an impact on EFL students' English comprehension and production in classrooms. The participants were 99 undergraduate students both male and female studying in the English major at Phibulsongkram Rajabhat University. The purpose of study was to find factors that had a positive impact on EFL students' English language comprehension and production and to investigate the relationships between the factors affecting students' English language comprehension and production. The questionnaire used in this study was a 5 point of Likert questionnaire. A Paired Two Sample T-test for Mean ( $\bar{X}$ ) was carried out to test the hypothesis of the study. The research findings revealed that there were five factors that had a positive impact on EFL students' English comprehension and production including motivation, attitude towards English, teachers' qualifications and characteristics, teaching and learning materials, and methods of teaching in classrooms is significant at the .05 level.
\end{abstract}

Keywords: language comprehension, language production, English comprehension, English production, EFL factors

\section{Introduction}

Language is an important and necessary tool for humans to communicate with each other. If we do not have language, it means that we cannot properly express our thoughts to others so that they can understand us nor can we participate in any social activities that occur (Di Pietro, 1994). Also it is very significant for educational purposes. When teachers explain or instruct students, they have to use language as a tool in the classroom. Furthermore, ADEA (2005) stated that "Language is not everything in education, but without language, everything is nothing in education". So, there is no one who denies that language plays an essential role in teaching and learning.

One of the languages used in many classrooms around the world is English. As we know English is used as a tool in a lot of classrooms in many parts of the world including Asia, as it is taught as a foreign language (EFL: English as a Foreign Language). In different countries, English is a compulsory subject that all students must study in an educational system. For example, Thai students have been required to study English as a foreign language since primary school. However, there is nothing to guarantee that the students achieve any English proficiency or that they are skilled in listening, speaking, reading, or writing. Additionally, comprehension in a language is important for learners to produce or use their skills in English effectively. For these reasons, there needs to be an investigation into the factors related for students to enhance their English skills and find out what factors affect EFL students' comprehension and production in English classroom. The results of the study are possibly advantageous for teachers who would like to design class or teaching techniques effectively in the future.

\section{Review of Literature}

\subsection{English language comprehension and production}

Language comprehension and production is one of the most important aspects investigated by many researchers in the field of English language teaching because there are many different studies to support that language comprehension and production are necessary to the process (Clifton \& et al., 2013) such as the process of recognizing and producing words and understanding and creating sentences in English. In addition to the findings of Kemper \& Herman (2020), who indicated that language comprehension is a significant issue for the day to day functions of adult learner. Both of them expressed that comprehension of written and spoken language depends on the learners' capability to select or process words and phrase meanings, clauses and sentence grammar including discourse and language structure. Whereas some of the research focused on the production of language related to speech or spoken words and comprehension of both written and spoken words. Besides, there are some indications that language comprehension is relevant to reading and listening as well. 
When the readers or listeners read or listen to sentences, they have to attempt to relate each new phrase to the phrase currently being processed and try to understand the lexical meaning they are reading and listening to understand and to reply with correct answers.

Therefore, the notion of language comprehension and production cannot be separated completely. MacDonald (2013) revealed that language production processes can provide an insight into how language comprehension works and language typology and he also expressed that basic features of comprehension to production processes that can shape language formation. According to the findings of Pickering \& Garrod (2013), they investigated a theory of language production and comprehension and found that both were regarded as quite distinct in language processing to develop language skills; nevertheless, they considered that production and comprehension were forms of action, action perception, and joint action. Most of language forms are incorporated with well-defined levels of linguistics such as semantics, syntax, and phonology. For example, the ability to read and understand correctly also relates to ones' abilities to recognize and comprehend the meaning of a series of words, phrases and sentences, to understand the central theme of a passage or to understand oral reading skills such as expression, pitch, volume, stress and intonation. Similarly, the ability to write is first relevant to comprehension and finally it is also related to language production for example, ability to recognize and understand words, phrases, and sentence structure including how to use punctuation marks, and accurate spelling until the learners are able to engage in personal and formal writing correctly (Nath, 2015).

\subsection{English Learning and Teaching}

The process of effective learning and teaching in class is related to several significant components such as practical curriculums, qualified teachers, active students, supportive materials and so on. However, the two major constituents in a bilingual classroom are the teacher and the learners. Language learning in class does not depend only on the teacher. Quist (2000) stated that the students correspondingly had been expected to show more participation and responsibility for the language learning process. Vuzo (2010) mentioned that the entire process of learning and teaching English language, requires that the interactions between teachers and learners must occur together. If both of them interact, this can create intellectual and practical activities and eventually to succeed in effective English language learning.

Not only do teachers and students play a major role in English language classrooms but teaching materials are also one of the most crucial parts of a class. The teaching materials can be things that encourage or stimulate learners to feel more participative and engaged in the activities in the class. Additionally, Kapoli (2001) indicated that practical teaching materials can likely be real experiences which enable learners to have an opportunity to practice and use their target language more authentically.

However, Lamb (2002) reported that achievements in English language learning was also relevant to learning circumstances such as class sizes, backgrounds of learners, the physical state of the class, or the frequency of using the target language. Students are able to learn a foreign language when they are stimulated by their surroundings. For example, large class sizes is possibly a factor that causes learners to not achieve learning foreign languages because the teachers cannot instruct them individually when learners suffer any difficulties in class. Additionally, different background of language learners makes English language learning ineffective. Variety of background of English proficiency makes a lot of teachers in difficulty to arrange their class efficiently. For the case that students who have higher English proficiency, this causes groups of learners to love to study and participate in English activities in class. In contrast, if learners have little knowledge of English, they will most likely feel discouraged to take part in any English activities in class Therefore, the circumstances of learning is one issue that can affect foreign language learners to accomplish in learning English.

\subsection{Motivation towards Language Learning}

Learning a new foreign language is likely engaging different components of learners such as pronunciation, vocabulary, grammar or even culture. This means that students must encounter many new elements when learning a foreign language. Hence, motivation towards learning a new target language is vital for learners to encourage them to learn the new language positively. According to Rueda and Chen (2005), they stated that language learning motivation can be defined as an orientation of a new language learner which is likely the goal of learning a second or foreign language. There are many second or foreign language learning researchers who have underlined that motivation towards language learning is one of the most significant factors in foreign language learning achievement. The two types of motivation that have been generally identified by researchers are extrinsic and intrinsic.

Motivation coming from outside of the learners such as motivation resulting from reinforcement in the form of high test scores, or teacher compliments is defined as an extrinsic motivation. 
Meanwhile, a response to needs existing within the learner, for instance, curiosity, and feelings of competence or growth is referred to an intrinsic motivation (Eggen and Kauchak, 1994). Consequently, the motivation that comes from the language learners sometimes appears as behavior or it can be stated that behavior as motivational reinforcement. According to Gardner (2006), he mentioned that "Students with higher levels of motivation will do better than students with lower levels" and "If one is motivated, he/she has reasons (motives) for engaging in the relevant activities".

\subsection{Students' Attitudes towards Language Learning}

According to motivational perspectives involved in foreign language learning, attitude towards the new language is necessary for learning a new one. If learners are inspired or motivated to study the new target language, they may mention that they ultimately have a positive attitude towards that language. There are three typical components of attitude: cognitive, affective and behavioral (Baker, 1992).

The cognitive component is related to thoughts and beliefs. A satisfaction or favorable attitude to the foreign language probably leads to higher participation and appreciation in learning the language and eventually succeeding in the target language.

The affective component involves a positive attitude to the foreign language being learnt. The feeling includes love or hate of the language, a passion for foreign novels, songs, or movies, or anxiety about learning the foreign language.

The behavioral component refers to ones willingness to perform or act in any situation. It is behavior occurring under specific circumstances. For example, a person with a positive attitude towards English or any foreign language is assumed that he or she is ready to learn the new foreign language without influence. Eventually, the language learners will be able to achieve a higher level of learning the new nonnative language much more easily.

\section{Conceptual Framework}

A conceptual framework is a set of coherent concepts. The conceptual framework in this study was adopted and based on a model of evaluation from Bloom's (1982), including the evaluation of four major components: teachers, students, teaching and learning materials, and methods of teaching. All of the four components are independent variables which are set up to find out how they are affecting each student performance in an English class as dependent variables. The performance of students was based on language comprehension and production. Some variables of the study and some questions in the questionnaires are adopted from the research of Mosha (2014).The researcher describes a set of comprehensible concepts that make it easy to understand the conceptual framework of the study illustrated in Figure 1 


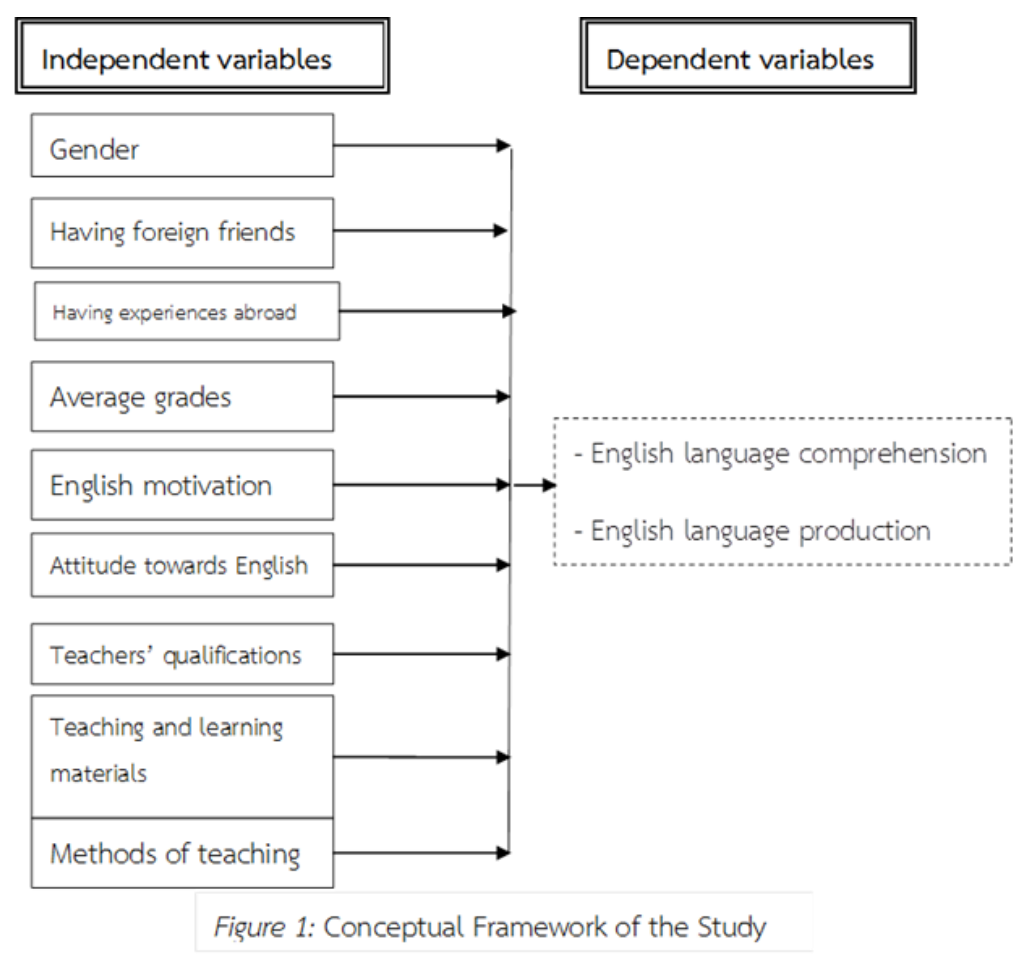

\section{Purposes of the Study}

1. To investigate factors that have a positive impact on EFL students' English language comprehension and English language production.

2. To investigate the relationships between the factors impacting on students' English language comprehension and English language production.

\section{Research Questions}

What factors have a positive impact on EFL students' English language comprehension and English language production in classrooms?

\section{Hypothesis of the Study}

$\mathrm{H}_{0}$ : There are positive relationships between average English grades and English language comprehension.

$\mathrm{H}_{1}$ : There are no positive relationships between average English grades and English language comprehension.

\section{Research Design}

This research is a quantitative study. The participants of the study were students who have studied English as a foreign language and they have been taught by teachers who are not English native speakers. The purpose of this research was to investigate related factors that affect EFL students' interaction and performance in English class. A survey method was designed to attain the stated objective. The instrument of the research was a questionnaire and the data collection method was done by distributing the questionnaire to the EFL students. Once the questionnaires had been completed by the students, the researcher collected all of the data.

\section{Participants of the Study}

The sampling of the study was 99 undergraduate students both male and female, studying in the English major at Phibulsongkram Rajabhat University. The participants are purposive samplings according to the table of Krejcie \& Morgan at the level of 0.5. The participants were comprised of 29 males (28.71\%) and 70 females (69.30\%). All the participants had been taught English by Thai and native English teachers. Thai teachers have taught them in the subjects of English grammar, writing, and reading. Meanwhile, the natives had taught them listening and speaking in English. 


\section{Research Instrument}

A questionnaire was the research tool which consisted of three sections. The first section was about the demographic information of the respondents which included gender, having foreign friends, having experiences abroad, and average English grades. The second section was comprised of questions about EFL students' motivation and attitude towards English. The third section included questions about teachers' qualifications, teaching and learning materials, and methods of teaching in English classrooms. All questions in the second and the third parts were Likert-type items consisting of 5 levels of agreement. The questionnaire was evaluated the reliability with Cronbach's Alpha and found the reliability of the questionnaire at 0.99 . The participants were asked to answer the questions. After that all the questionnaires were collected to analyze the result of the study.

\section{Data Analysis}

The data from the study was arranged depending on the purposes of the study and then the demographic information of respondents and the questions from the Likert-type items was analyzed by measuring the percentage (\%), mean $(\bar{X})$ and standard deviation (S.D). At the stage of finding of correlation between the variables, it was analyzed by using Pearson's correlation coefficient (Simple correlation) and a t-test was used as a hypothesis testing tool for the two groups in the study.

\section{Results of the Study}

Based on the conceptual framework of the study which included the independent variables (gender, having foreign friends, having experiences abroad, average grades, English motivation, attitude towards English, teachers' qualifications, teaching and learning materials, and methods of teaching), and the dependent variables included English language comprehension and English language production, the results from the study were reported in two parts according to the two aims of the study. However, the findings were demonstrated by descriptive statistics by the respondents' demographic as a percentage (\%), mean score $(\bar{X})$ and standard deviation (S.D).

Additionally, the results presented the relationship between independent and dependent variables by Pearson's correlation coefficient and hypotheses of the study tested by a t-test.

For the first set of data analysis, the demographic of the samplings was presented in Table 1. There were 99 students studying English major which consisted of 29 males equal to $28.71 \%$ and 70 females equal to $69.30 \%$. Also, the number of the students having foreign friends and no foreign friends was slightly different. The findings indicated that 49 students had foreign friends (48.51\%) and that 50 students had no foreign friends (49.50\%).

On the contrary, the number of students having experiences and no experiences abroad was very different. Only 19 students had had any experience overseas equal to $18.81 \%$, whereas 80 students had had experiences overseas, equal to $79.20 \%$. Moreover, the number of the students with average grades in all English subjects in the study were classified by five classes consisting of $\mathrm{A}, \mathrm{B}^{+}-\mathrm{B}, \mathrm{C}^{+}-\mathrm{C}, \mathrm{D}^{+}-\mathrm{D}$, and $\mathrm{F}$. It could be presented as follows: students that earned an $\mathrm{A}$ as $8, \mathrm{~B}^{+}-\mathrm{B}$ as $33, \mathrm{C}^{+}-\mathrm{C}$ as 48 which was the most number of the students got average English grades, $\mathrm{D}^{+}-\mathrm{D}$ as 10 , and $\mathrm{F}$ as 0 .

Table 1: Demographic of the sampling of the study

\begin{tabular}{|c|c|c|c|}
\hline & & $\begin{array}{l}\text { Number } \\
\text { of Sampling } \\
\text { (n) }\end{array}$ & $\begin{array}{l}\text { Percentage } \\
(\%)\end{array}$ \\
\hline \multirow[t]{2}{*}{ Gender } & Male & 29 & 28.71 \\
\hline & Female & 70 & 69.30 \\
\hline \multirow{2}{*}{$\begin{array}{l}\text { Students having } \\
\text { foreign friends }\end{array}$} & Yes & 49 & 48.51 \\
\hline & No & 50 & 49.50 \\
\hline \multirow{2}{*}{$\begin{array}{l}\text { Students having } \\
\text { experiences abroad }\end{array}$} & Yes & 19 & 18.81 \\
\hline & No & 80 & 79.20 \\
\hline Average English & $\mathrm{A}$ & 8 & 7.92 \\
\hline \multirow[t]{3}{*}{ Grade } & $\mathrm{B}^{+}-\mathrm{B}$ & 33 & 32.67 \\
\hline & $\mathrm{C}^{+}-\mathrm{C}$ & 48 & 47.52 \\
\hline & $\mathrm{D}^{+}-\mathrm{D}$ & 10 & 9.90 \\
\hline
\end{tabular}


Secondly, the results of the study were delineated by the mean score $(\bar{X})$ and standard deviation (S.D) of statements from the questionnaires illustrated in Table 2. There were seven main topics in the questionnaire. All participants had to answer with their own opinions which indicated their level of agreement on the 5 point Likert scales of the statements in the questionnaire. There were 70 statements presented in the questionnaire including topics related to English motivation, attitude towards English, teachers' qualifications and general characteristics, teaching and learning materials, methods of teaching in English class, English language comprehension, and English language production. The topic which had the highest mean score was related to teaching and learning materials. A mean $(\bar{X})$ of 3.77 and a standard deviation of 1.05 whilst the topic related to English language production had the lowest mean score of 3.21 and a standard deviation of 0.51. For the topic methods of teaching in English class, English motivation, teachers' qualifications and general characteristics, attitude towards English, English language comprehension all had an average scored of over 3.21 respectively which are all displayed in Table 2.

Table 2: Mean $\overline{(X)}$ and Standard Deviation (S.D) of seven topics on the questionnaire

\begin{tabular}{|c|c|c|}
\hline Topics & $\operatorname{Mean} \overline{(X)}$ & $\begin{array}{l}\text { Standard Deviation } \\
\text { (S.D) }\end{array}$ \\
\hline English Motivation & 3.67 & 0.56 \\
\hline Attitude towards English & 3.51 & 0.59 \\
\hline $\begin{array}{l}\text { Teachers' qualifications and general } \\
\text { characteristics }\end{array}$ & 3.64 & 0.56 \\
\hline Teaching and learning materials & 3.77 & 1.05 \\
\hline Methods of teaching in English class & 3.69 & 0.58 \\
\hline English language comprehension & 3.37 & 0.48 \\
\hline English language production & 3.21 & 0.51 \\
\hline
\end{tabular}

Another set of analysis examined the relationship between variables. The nine independent variables were comprised of gender, students having foreign friends, students having experiences abroad, average English grades, English motivation, attitude towards English, teachers' qualifications and general charcateristics, teaching and learning materials, and methods of teaching in English class. The only two dependent variables consisted of English language comprehension and English language production. The statistical method used to investigate the relationship between independent and dependent variables was a two-tailed Pearson's product-moment correlation coefficient (r).

The statistic was employed to find the strength and direction of the variables' relationships which could be either a positive or negative direction.

The correlation of the variables was set at a significance of 0.05 level and all data from the study was investigated with the association between the variables was illustrated in Table 3. Additionally, the hypotheses of the study were also tested by a two tailed Pearson's product moment correlation coefficient (r).

Table 3: Correlation is significant at the 0.05 level $(p<0.05)$

\begin{tabular}{|c|c|c|}
\hline \multirow[b]{2}{*}{ Independent variables } & \multicolumn{2}{|l|}{ Dependent variables } \\
\hline & $\begin{array}{l}\text { English } \\
\text { comprehension } \\
\text { (r) }\end{array}$ & $\begin{array}{l}\text { English } \\
\text { production } \\
(\mathrm{r})\end{array}$ \\
\hline Gender & -0.300 & -0.239 \\
\hline Students having foreign friends & -0.107 & -0.178 \\
\hline Students having experiences abroad & -0.222 & -0.123 \\
\hline Average English Grades & -0.314 & -0.197 \\
\hline English Motivation & 0.569 & 0.533 \\
\hline Attitude towards English & 0.367 & 0.397 \\
\hline $\begin{array}{l}\text { Teachers' qualifications and general } \\
\text { characteristics }\end{array}$ & 0.418 & 0.352 \\
\hline Teaching and learning materials & 0.105 & 0.067 \\
\hline Methods of teaching in English classes & 0.256 & 0.256 \\
\hline
\end{tabular}

As demonstrated in the following table, the correlation between variables could range from negative to positive. The first direction of the relationship was associated between gender and English language comprehension was negative 
and the correlation coefficient was $-0.30(r=-0.30, p<0.05)$. Similarly, the relationship between gender and English language production was negative and the correlation coefficient was $-0.239(r=-0.239, p<0.05)$. Another pair of relationships from the variables was between students having foreign friends and English language comprehension. The correlation was negative at $-0.107(r=-0.107, p<0.05)$. Likewise, the correlation coefficient between students having foreign friends and English language production was -0.178. For the students having experiences abroad, the relationship associated with English language comprehension and English language production were both negative as well. The correlation between students having experiences abroad and English language comprehension was $-0.222((r$ $=-0.222, p<0.05)$ and English language production was at $-0.123(r=-0.123, p<0.05)$. Also, the correlation coefficient between average English grades and English language comprehension was- $0.314(r=-0.314, p<0.05)$. Another negative relationship was between average English grades and English language production which scored a correlation coefficient of $-0.197(r=-0.197, p<0.05)$.

The other set of analysis examined the relationship between the variables were positive with a significant correlation at the 0.05 level. The first pair of positive relationships was between English motivation and English language comprehension with a $0.569(r=0.569, p<0.05)$. The correlation coefficient of English motivation and English language production was $0.533(r=0.533, p<0.05)$. The results from the correlation between attitude towards English and English language comprehension was $0.367(r=0.367, p<0.05)$ and English language production was $0.397(r=$ 0.397, $p<0.05$ ) which were both positive. Besides, the relationship between teachers' qualifications and general characteristics and English language comprehension was at a positive level of $0.418(r=0.418, p<0.05)$ which was similar to the relationship between teachers' qualifications and general characteristics and English language production at $0.352(r=0.352, p<0.05)$. The correlation between teaching and learning material and English language comprehension was also positive at $0.105(r=0.105, p<0.05)$ and the correlation between teaching and learning materials and English language production was at $0.067(r=0.067, p<0.05)$. The correlation between methods of teaching in English class and English language comprehension was the same as the correlation between methods of teaching in English class and English language production at $0.256(r=0.256, p<0.05)$.

In conclusion, the results of the study could be summarized that the relationships between these sets of variables were both negative and positive. The results were based on the scores from the Pearson's correlation analysis and showed that the $r$-value can be inferred and that the first hypothesis of the study was rejected $\left(H_{0}\right.$ : There are positive relationships between average English grades and English language comprehension). According to the r-value, it could be concluded that relationship between average English grades and English language comprehension was negative. It could be inferred that although the students whose average English grades were high, it does not mean that their English language comprehension will be proficient. Therefore, the first hypothesis is unacceptable but the second hypothesis $\left(H_{1}\right.$ : There are no positive relationships between average English grades and English language comprehension) could be acceptable.

Moreover, according to the $r$-value derived from the correlation, there are five independent variables (English motivation, attitude towards English, teachers' qualifications and general characteristics, teaching and learning materials, and methods of teaching in English class) correlated to English language comprehension and English language production positively and significantly. In other words, it could be concluded that they will have a level of English comprehension and production if the students are significantly motivated and have a positive attitude towards English. Furthermore, if the teachers' qualifications and general characteristics, teaching and learning materials and methods of teaching in English class are productive, English language comprehension and production will improve learners proficiently. Especially, based on the correlation between an independent variable, English motivation and other dependent variables, English language comprehension $(r=0.569, \mathrm{p}<0.05)$ and production $(r=0.533, \mathrm{p}<0.05)$, that out of these pairs of variables, they had the highest positive relationship. This result could be deduced that those who are highly motivated in English could have higher levels of English comprehension and production.

\section{Conclusion and Discussion}

The purpose of this study was to investigate factors that have a positive impact on EFL students' English language comprehension and English language production and to investigate the relationships between the factors impacting on students' English language comprehension and English language production. From the initial results of the study, it could be presumed that the five factors have a positive impact on English language comprehension and production.

The five factors included are English motivation, attitude towards English, teachers' qualifications and general characteristics, teaching and learning materials, and methods of teaching in English classes. From the findings of this study it could be inferred that there is a relationships between those who have a high level of English comprehension or 
skills and the five factors previously mentioned. Moreover, the results based on the analysis can be an answer of the second purpose to find the relationships among the factors affected to EFL learners' English comprehension and English production. The findings of the second aim reveals that the learners who scores highly at the five factors correlated positively and significantly at the 0.05 level to EFL student's English comprehension and English production. Therefore, when a teacher would like to design a lesson for EFL students to improve their skills in English, it is important to be aware of how to support the students so that they are motivated and have a positive attitude towards English because those who appreciate learning will probably believe that they can improve on what they are doing.

Moreover, the factors that lead learners to comprehend English and help them to perform or understand English in this study are not only related to motivation and attitude towards English, there is also a correlation between teachers' qualifications and general characteristics, teaching and learning materials, and methods of teaching in English classes. The results also support that students' achievement in English correlate with teachers' qualifications and general characteristics such as having a pleasant appearance, correct pronunciations, and clear explanations. Moreover, teaching and learning materials such as interesting textbooks, internet or computer assistant, and method of teaching in English class such as preparing classes, organizing games in class, or controlling the class correlated positively to enhance students' English comprehension and production.

However, based on the results of the study there are still some factors or variables not related to improving learners' capability in English comprehension or production, for example, gender, having foreign friends, having experiences abroad, and average English grades. The correlation derived from Pearson's correlation analysis presented these variables related to the English skills of learners negatively. According to the results, there is no indication that males have higher comprehension or production skills in English compared to females. Furthermore, those who have foreign friends or those who have had overseas experience have greater comprehension or production skills than those who do not have. The students who have never been aboard may have good comprehension in reading and listening if they have a positive attitude and are motivated. Similarly, those who get higher average scores or grades in English disassociate positively to English comprehension and production. Sometimes, students that get lower average scores in English have possibly comprehended well in English and they may have also performed proficiently in English. Therefore, it could be concluded that gender, having foreign friends, experienced overseas, or received high average English grades are not associated positively with students' abilities of English reading comprehension and English speaking or listening.

Findings of this case study provide that a student's sense of accomplishment in English are correlated by three main aspects which consist of students' interests, teachers' traits and characteristics, and pedagogy. The discussion is presented as follows:

1. Students' interest is one of the predictor for learners' success or a sense of students' achievements. An interest in English learning is relevant to learners' personal attitude and motivation or it could be stated that ones' sense of achievement is the feeling or awareness of personal accomplishment and success (Brady \& Tsay, 2010).

For this reason, it is logical to indicate that those who have a positive feeling towards learning English or have the notion that English is important for them to be successful. This notion is supported by the research done by EL-Omari (2016) investigated factors affecting students' achievements in English language learning were significantly related to attitudinal factors. He found that the students who enjoyed learning English and were willing to learn English with the percentage of $86 \%$ had a positive attitude. Furthermore, not only is ones' attitude towards English a significant factor but also ones' motivation in English language is another important factor among students studying English. The findings of Wimolmas (2013) who investigated the main factors affecting English language learning of 30 first year undergraduate students at an international institute of engineering and technology in Thailand and found that the students were relatively highly motivated in learning English. The results indicated that instrumental motivation is a crucial factor among this group of students learning English so that they can enhance and improve their English. Also, there were indicators that motivation is effective and that a students' level of competence are positively affected while they studying English language. Similarly, the findings of this case study showed there is a correlation between motivated and attitudinal factors and English language comprehension and English language production which are positively significant. Therefore, it can be deduced that students' interests, especially attitude and motivation, are important in learning English effectively and competently.

2. Teachers' personal traits and characteristics is one of the factors that affects English language learning. The proficiency and efficiency of the learners are sometimes based on teachers and instructors in the class. According to Thompson (2008), he stated that not only are good teaching skills of teachers necessary for students, but also teachers' 
personal characteristics were important because the teachers usually played a crucial role in students' successful learning. Additionally, Prabhu (1990) supported that the friendly characteristics of EFL teachers correlated with escalating rapport between learners and teachers. This could probably be related to students' learning productively and could encourage the students to learn efficiently. Similarly, the study done by Chen (2012) who investigated favorable and unfavorable characteristics of EFL teachers in Thailand found that classroom teaching was related to the personal traits of teachers' emotions, kindness, fairness, lenience, and responsibility, etc. In addition to the research done by McDermott \& Rothenberg (2000), they showed that most of the students loved to learn with the teachers who had a sense of humor and the teachers who made lots of fun because the teachers could break the ice and made the learners feel relaxed during studying in class. Therefore, these studies stated previously can support that this case study found that teachers' qualifications such as being good-looking and elegant, knowing a lot, having good pronunciation, speaking fluently, or being fair and impartial with grades and punishments was positively related to English language comprehension and production.

3. Pedagogy is also accepted as one of the factors that has an impact on learning English. According to the results of this case study, it found that teaching and learning materials and methods of teaching in English classes correlated with learners' English comprehension and production positively. This could indicate that effective learning requires good pedagogy including methods of teaching such as preparing classes, organizing games in class or creating a relaxed classroom atmosphere, and teaching materials such as interesting and motivating English textbooks, quality videos and recording or computers and internet as all necessary curricular materials. It is interesting to discover that the methods and techniques of lesson delivery are important for good teaching skills and techniques to ensure that the content is clear and comprehensible (Chen, 2012). Additionally, the research done by Chen supported that EFL pedagogy was concerned with characteristics of lesson delivery, language used while teaching, classroom activity organization and classroom atmosphere creation. Furthermore, the study done by El-Omari (2016) revealed that extracurricular factors such as providing English newspapers, magazines, videos, radios, books, and dictionaries for EFL students could help the learners higher levels achieve of English proficiency because those extracurricular factors played a vital role in language learning.

In summary, the accomplishment of both English language comprehension and English language production is affected by many factors, which foreign language learners and teachers should be aware of. Especially, students' attitude and motivation, teachers' personal characteristics, and pedagogy are crucial extracurricular factors to benefit the EFL learners effectively and proficiently.

\section{Limitations and Recommendations}

There are still some limitations for the present study. The data was collected with only 99 undergraduate students both male and female, studying in the English major at Phibulsongkram Rajabhat University, which was not able to be most of Thai representatives. Therefore, future research should investigate more participants from more different majors, faculties, and universities to find whether other factors have more impacts on other different students or not.

\section{Acknowledgements}

Preparation of the research was supported by grants from the Personnel Development Fund of Education Service Division, Pibulsongkram Rajabhat University 2018 Academic year.

This study greatly benefitted from comments by members of the English Program at the Faculty of Humanities and Social Sciences, Pibulsongkram Rajabhat University. Aslo, English language in this study was willingly edited by Mr. David Joseph Preyer. Errors are of course my own.

\section{References}

Association for the Development in Africa. (2005). Conference on bilingual education the use of local languages in education. International Education Journal, 17(2), 1-5.

Baker, C. (1992). Attitude and language: WBC Print Ltd, Bridgend.

Baker, C. (2006). Foundations of Bilingual Education and Bilingualism. The United State of America: Library of Congress Cataloging in Publication Data.

Bloom, B. (1982). Human characteristics and second language learning. New York, NY: McGraw-Hill.

Brady, M., \& Tsay, M. (2010). A Case Study of Cooperative Learning and Communication Pedagogy: Does Working in Teams Make a Difference? Journal of the Scholarship of Teaching and Learning, 10, 78-89.

Chen, J. (2012). Favorable and Unfavorable Characteristics of EFL Teachers Percieved by University Students of Thailand. International Journal of English Linguistics, 2(1), 213-219. 
Clifton C., et al. (2013). Language Comprehension and Production. Comprehensive handbook of psychology. United States: Wiley.

Di Pietro, R. (1994). Helping people do things with English. In Kral, T. Teacher development: Making the right moves. Washington, DC: English Language Programmes Division.

Eggen P., \& Kauchak, D. (1994). Educational psychology classroom connection (second edition). New York: Macmillan College Publishing Company.

EL-Omari, A. (2016). Factors Affecting Students' Achievement in English Language Learning. Journal of Education and Social Research, 6(2), 9-18.

Gardner, R. (2006). The socio-educational model of second language acquisition: A research paradigm. EUROSLA Yearbook (6), 237-260.

Kapoli, I. J. (2001). The impact English language as a medium of instruction on the training and performance of secretaries. (Unpublished master's thesis). University of Dar es Salaam, Dar es Salaam.

Kemper, S., \& Herman, R. E. (2020). Language Comprehension. Retrived May 17, 2020, from https://www.encyclopedia.com/education/encyclopedias-almanacs-transcripts-and-maps/languagecomprehension.

Lamb, M. (2002). Explaining successful language learning in difficult circumstance. Prospect, 17(2), 35-52.

MacDonald, M. C. (2013). How language production shapes language form and comprehension. Hypothesis and Theory Article, 4(1), 1-15.

McDermott, P., \& Rothenberg, J. (2000). The characteristics of effective teachers in high poverty schools: Triangulation our data. Paper presented at the annual meeting of the American Educational Research Association, New Orleans. (ERIC Document Reproduction Service No. ED442887). Educational Research Association, New Orleans.

Mosha, M. (2014). Factors Affecting Students' Performance in English Language in Zanzibar Rural and Urban Secondary Schools. Journal of Education and Practice, 5(35), 64-76.

Nath, B.K., \& Sreeja, K.S. (2015). Language Comprehension Theories and Basic Language Skills. Retrived May 10, 2020, from https://www.researchgate.net/publication/

303942424_Language_Comprehension_Theories_and_Basic_Language_Skills

Pickering, M.J., \& Garrod, S. (2013). An integrated theory of language production and comprehension. Behavioral and Brain Sciences, 36(04). 329-347.

Prabhu, N. S. (1990). There is no best method-Why? TESOL Quarterly, 24: 232-338.

Quist, D. (2000). Primary teaching methods. London: Macmillan.

Rueda R., \& Chen, C.B. (2005). Assessing Motivational Factors in Foreign Language Learning: Cultural Variation in Key Constructs. Educational Assessment, 10(3), 209-229.

Thompson, S. (2008). Defining a good teacher simply! Modern English Teacher, 17(1): 5-14.

Vuzo, M. (2010). Exclusion through Language: A reflection on classroom discourse in Tanzanian Secondary Schools. Papers in Education and Development, 29, 14-36.

Wimolmas, R. (2013). A survey study of motivation in English language learning of first year undergraduate students at Sirindhorn International Institute of Technology (SIIT), Thammasat University. Bangkok: Thammasat University Press. 